\title{
A review of the platanaceous woods from the Eocene paratropical rainforest of south-east England
}

\author{
IMOGEN POOLE ${ }^{1, *}$, KEVIN L. DAVIES ${ }^{2}$ and HAZEL P. WILKINSON ${ }^{3}$ \\ ${ }^{1}$ Wood Anatomy Section, National Herbarium of the Netherlands, University of Utrecht Branch, PO \\ Box 80102, 3585 CS Utrecht, the Netherlands \\ ${ }^{2}$ Department of Earth Sciences, Cardiff University, PO Box 914, Cardiff, CF10 3YE, Wales, UK \\ ${ }^{3}$ Jodrell Laboratory, Royal Botanic Gardens, Kew, Richmond, Surrey, TW9 3DS, England, UK
}

Received November 2001; accepted for publication March 2002

\begin{abstract}
Small diameter pyritized axes, commonly referred to as 'twigs', of fossil platanaceous wood are described from the Lower Eocene London Clay Formation of south-east England. These twigs are characterized by solitary vessels with scalariform perforation plates, opposite intervessel pits, and tall, multiseriate rays that dilate in the phloem region. The wood anatomy supports close relationship to members of extant Platanaceae and the material is placed in the organ genus Plataninium Unger erected for fossil woods with close anatomical similarity to Platanus L. This material supplements the fossil record of platanaceous type wood from the Eocene London Clay and documents the first record of Plataninium decipiens Brett in the twig flora. (c) 2002 The Linnean Society of London, Botanical Journal of the Linnean Society, 2002, 139, 181-191.
\end{abstract}

ADDITIONAL KEYWORDS: fossil - London Clay - Platanaceae - Tertiary.

\section{INTRODUCTION}

Fossil floras often comprise a number of different components such as leaves, wood, flowers, fruits, seeds and pollen. These yield important information about past environments in that they are a source of data that supplement and complement that provided by the geological record. The pyritized flora from the Eocene (Ypresian) London Clay Formation in both the London and Hampshire Basins of south-east England is one such flora. Here, the wealth of information provided over the last three centuries has enabled us to understand one of the world's most varied fossil floras. Moreover, it is the only diverse flora from the Lower Eocene strata in Europe and affords detailed insights into the ecology of south-east England during the early Eocene, some 52-49 Mya. Close similarities have been shown to exist between the London Clay fossil flora and extant Indo-Malaysian rainforests (Reid \& Chandler, 1933; Poole, 1993) suggesting that a relatively warm, paratropical climate prevailed over south-east

*Corresponding author. E-mail: i.poole@geo.uu.nl
England during the Eocene. Even though this assemblage has been intensively studied, new and old localities in both the London and Hampshire Basins continue to yield interesting material and this, coupled with improved techniques, has contributed significantly to our understanding of the preservation and composition of the flora. Unfortunately, pyritized material rapidly succumbs to oxidation and although a number of techniques (e.g. Cornish, 1987 and references therein) are known to retard the process, hitherto, it has not been possible to prevent decay completely. The small diameter woody pyritized axes that include twig material, stems, small roots, fern axes and splinters of larger diameter axes such as branches or trunks, are traditionally referred to as 'twigs'. These twigs form one important component of the London Clay flora. They, together with fruits, seeds and remains of animals are washed out of the clay by wave action and are deposited on foreshores in the London and Hampshire Basins. The twigs, when compared with the fruits, seeds and pollen, have received comparatively little attention. Nevertheless, they are often well-preserved anatomically and can 
be used in systematic studies, thus furthering our understanding of a northerly $\left(41^{\circ} \mathrm{N}\right)$ Lower Eocene paratropical ecosystem.

\section{MATERIAL AND METHODS}

The specimens discussed below are from a representative selection of over 100 specimens so far collected of this xylotype. They all originate from either the London Basin: Warden Point (NGR 021724; specimens V.64748-V.64757) and Hens Brook (NGR 996731 King, 1984; V.64758-V.64759) on the Isle of Sheppey, Herne Bay (NGR 177685 eastwards; V.64760-V.64761), or from the foreshore at Bognor Regis (NGR 9148-9398; V.64762) in the Hampshire Basin. The remaining material of this xylotype is less well preserved or lacks diagnostic anatomical characters and therefore has not been included in this study. Nevertheless, the relative abundance of platanaceous specimens indicates that they formed a significant percentage of the twig flora. The specimens were sectioned as described by Poole (1993), subjected to a fine polishing technique (Kenrick \& Edwards, 1988) and studied using a reflected light, mineralogical microscope. Fractured surfaces and surface-etched (for $24 \mathrm{~h}$ in fuming nitric acid) material were studied using scanning electron microscopy. The specimens were deposited in the National History Museum (London).

Familial affinities were determined by consulting reference descriptions, such as those of Metcalfe \& Chalk (1950, 1983), Miles (1978), Schweingruber (1990), Ilic (1991) and by searches of the computerized OPCN (Wheeler et al., 1986; LaPasha \& Wheeler, 1987) and CSIRO Family Key (Ilic, 1987) wood databases. Such aids are useful in identification to family level even though they are primarily designed to help in the identification of mature wood samples. Subsequently, specimens were compared with extant wood samples, regardless of their geographical origin, housed in the Jodrell Laboratory, RBG, Kew and the National Herbarium of the Netherlands, Utrecht Branch. Wherever possible, the wood is described and measurements undertaken in accordance with the recommendations outlined by the International Association of Wood Anatomists (IAWA Committee,
1989) except in the case of fibre and vessel element length. These measurements, for both fossil and modern wood, were taken from thin sections (to ensure consistency) as macerations of fossil material were not possible. For the purpose of this study the term 'twig' refers to the fossil material and 'stem' refers to extant material of small diameter used in the comparative studies. Plant authorities are in accordance with those listed in Brummitt \& Powell (1992).

\section{SYSTEMATIC PALAEOBOTANY}

\author{
FAMily ?Platanaceae DUMORT. \\ ORGAN GENUS PLATANINIUM UNGER \\ Plataninium DECIPIENS BRETT
}

Other records: Plataninium sp. (Wilkinson, 1984)

Additional material: V.64748-V.64762

Emended species diagnosis. Secondary xylem; growth rings indistinct. Vessels solitary $(>70 \%)$, tangential diameter $<200 \mu \mathrm{m}$, intervascular pitting opposite to scalariform. Perforation plates totally scalariform or with very rare simple perforation plates. Rays mainly multiseriate up to 35 cells wide and $8 \mathrm{~mm}$ in height; rarely uniseriate. Ray cells mostly procumbent except at ray margins, crystals sometimes present. Wood parenchyma apotracheal diffuse and scanty, or as strings of cells, paratracheal.

Description. This description is based upon 15 pyritized small diameter axes measuring less than $24 \mathrm{~mm}$ in diameter and $60 \mathrm{~mm}$ in length. Cortex eroded. Phloem region preserved in nine specimens (V.64748V.64750, V.64752-V.64757). Triangular distal ends of rays separate phloem region into discrete triangular phloem 'wedges' (Figs 2, 6 and 22) where fibres and parenchyma and/or sieve elements can be distinguished (Fig. 22). The cambium in juxtaposition to rays intrudes deeply into the secondary xylem giving a 'corrugated' appearance at the junction between secondary xylem and phloem rays (Figs 2 and 22). Xylem diffuse porous. Growth rings absent. Vessels are small, solitary or occasionally paired due to overlapping end walls (Figs 1, 3,6 and 9). There are $\approx$

Figures 1-9. Anatomy of fossil Plataninium decipiens twigs. Fig. 1. Fractured transverse section (TS) of V.61671. Scale bar $=1 \mathrm{~mm}$. Fig. 2 . TS V.64748 showing dilating rays in the phloem region. Scale bar $=100 \mu \mathrm{m}$. Fig. 3 . TS V.64761 showing pith and xylem. Scale bar $=250 \mu \mathrm{m}$. Fig. 4. SEM V.64762 showing ?sheath cells (arrowed). Scale bar $=50 \mu \mathrm{m}$. Fig. 5. SEM scalariform perforation plate in 1/2/14 (personal collection; specimen now disintegrated). Scale bar $=15 \mu \mathrm{m}$. Fig. 6. Polished TS specimen V.64757. Scale bar $=500 \mu \mathrm{m}$. Fig. 7. Longitudinal section (LS) V.64762 showing some relatively thick-walled pith parenchyma cells. Scale bar $=300 \mu \mathrm{m}$. Fig. 8. LS thin-walled pith parenchyma cells in V.64761. Scale bar $=150 \mu \mathrm{m}$. Fig. 9. TS V.64761 showing uniseriate- and multiseriate rays and solitary, relatively angular vessels. Scale bar $=50 \mu \mathrm{m}$. 

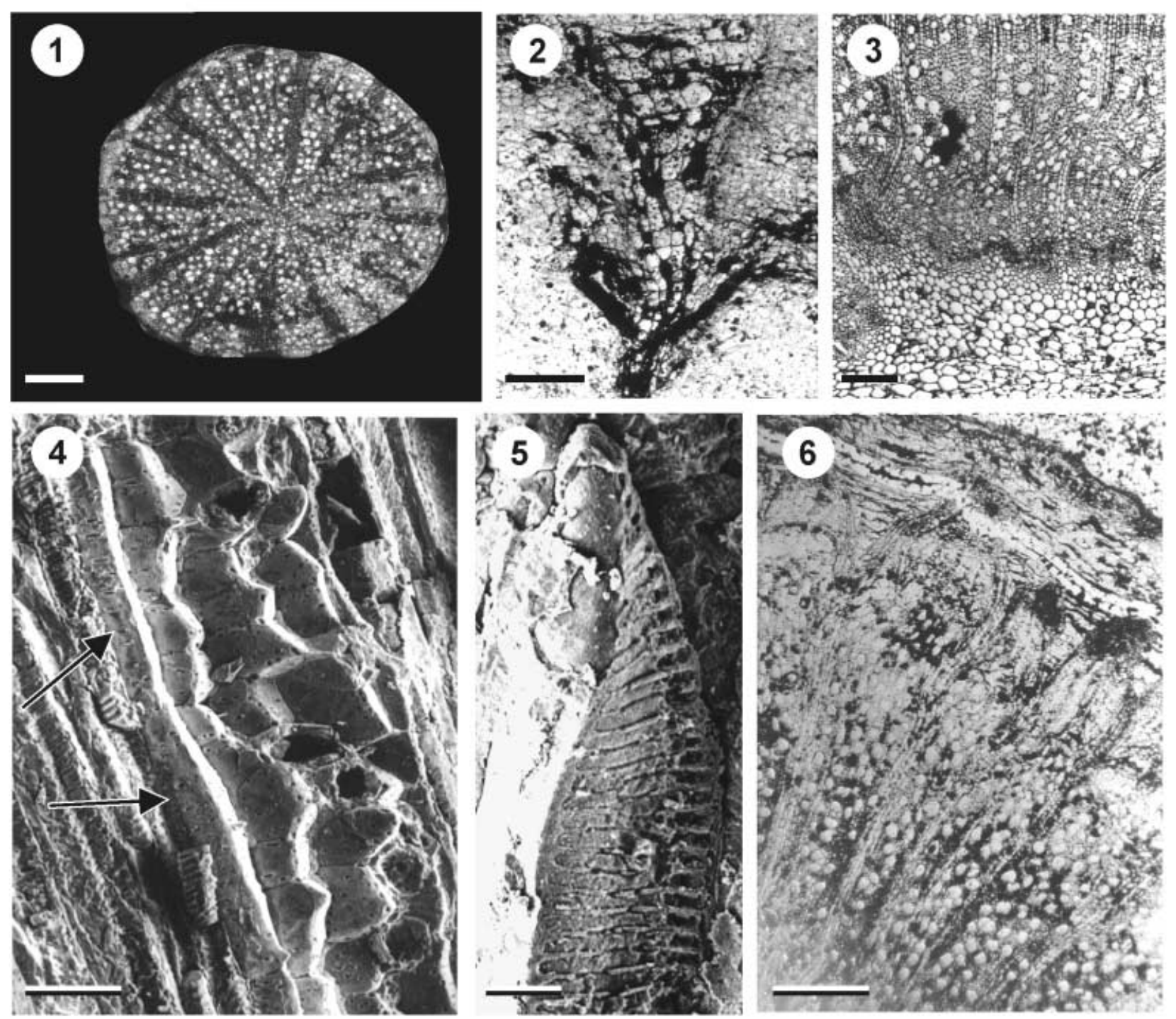

H. 7 in

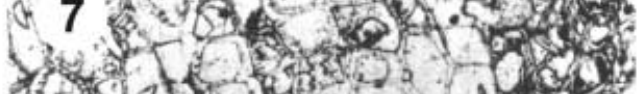

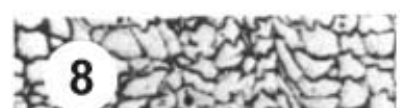
(1) 2.
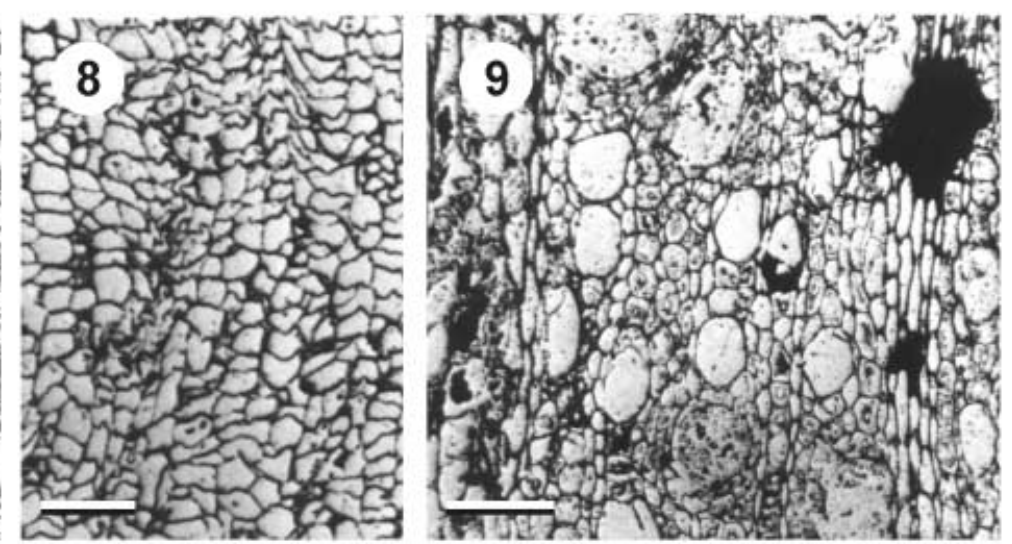
65 vessels $\mathrm{mm}^{-2}$ (range: $19-54 \mathrm{~mm}^{-2}$, rarely up to 200 ), with mean tangential diameter of $\approx 81 \mu \mathrm{m}$ (range: $30-290 \mu \mathrm{m}$ ), mean radial diameter of $\approx 107 \mu \mathrm{m}$ (range: $20-340 \mu \mathrm{m}$ ) and mean vessel element length of $\approx 792 \mu \mathrm{m}$ (range: $150-2500 \mu \mathrm{m}$ ). Intervessel pitting opposite, circular to scalariform with bordered pits measuring up to $22 \mu \mathrm{m}$ in diameter, very rarely more alternate. Tyloses occasionally present (Fig. 13). Perforation plates are scalariform (Figs 5, 10 and 13) with up to 22 bars per perforation plate. Rare simple perforation plates observed in specimens V.64759 and V.64760. Fibres are thin- to thick- walled with a mean diameter of $\approx 14.5 \mu \mathrm{m}$ (range: $8-30 \mu \mathrm{m}$ ) and mean length of $\approx 455 \mu \mathrm{m}$ (range: $150-600 \mu \mathrm{m}$ ). Fibre pitting

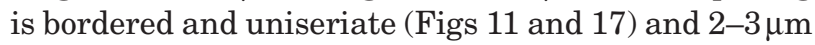
in diameter. Wood parenchyma could not easily be distinguished from the ground mass. Rays are mainly multiseriate (Figs 1 and 12), seldom uniseriate. Multiseriate rays range from (3-) 5-20 cells wide (mode is $\approx 9$ cells) and up to $8 \mathrm{~mm}$ in height. The constituent cells are mainly square, occasionally upright or procumbent (Fig. 14). Less than five rows of square marginal cells occur when a ray is composed mainly of procumbent cells. Two specimens (V.64760, V.64762) have possible sheath cells or simply a wood parenchyma strand in juxtaposition to the ray (Fig. 4). Ray-vessel pitting is opposite to gash-like and scalariform (Fig. 10), rarely more alternate. There are $\approx 1-6$ rays $\mathrm{mm}^{-1}$. No crystals in the ray cells were observed. The pith is absent from three of the specimens (V.64750, V.64759, V.64760). When present, the pith is composed mainly of thin-walled, homogeneous, isodiametric parenchyma cells (Figs 3 and 8), the majority of which have undergone degradation. Occasionally pith cells appear to have thickened walls (Fig. 7) and gash-like pitting (Fig. 21).

\section{IDENTIFICATION OF MATERIAL}

\section{COMPARISONS WITH EXTANT TAXA}

The combination of exclusively solitary vessels, opposite pits, fibres with distinctly bordered pits and rays, commonly over ten cells wide, occurs in Chloranthaceae, Dilleniaceae, Eupteleaceae, Ericaceae, Epacridaceae, Platanaceae and Icacinaceae. The Chloranthaceae have scalariform perforation plates with numerous fine bars, numerous uniseriate rays and multiseriate rays composed of upright cells; Eupteleaceae stem woods have scalariform perforation plates with numerous bars, heterogeneous rays and small (i.e. $<30 \mu \mathrm{m}$ ), abundant vessels in radial rows and parenchyma in terminal bands; Epacridaceae have spiral thickenings in the stem wood along with numerous and narrow (uniseriate and biseriate) rays and small diameter vessels. Predominantly scalariform perforation plates occur together with few simple perforation plates found in the Dilleniaceae, Ericaceae and Platanaceae. The Dilleniaceae have larger diameter vessels (i.e. $>100 \mu \mathrm{m}$ ) with numerous (i.e. $>100$ ) bars per scalariform perforation plate and rays of two distinct sizes. Ericaceae stem woods have abundant uniseriate rays and small (i.e. typically $<50 \mu \mathrm{m}$, typically $<25 \mu \mathrm{m}$ ) diameter vessels. Thus, the Icacinaceae and the Platanaceae most closely resemble our fossil material. Icacinaceae stem woods have no dilating rays in the phloem region; mature wood exhibits a range of unspecialized to specialized forms (Metcalfe \& Chalk, 1950) with small vessels often in radial multiples. This family also has sheath cells associated with the multiseriate rays. Members of the Platanaceae (Figs 15,16,18-21) are very similar to the Icacinaceae but have homogeneous rays that dilate in the phloem region. Where the phloem region is still present, fossil material most closely resembles Platanaceae, but this is not so obvious when the phloem has been eroded. Süss \& Müller-Stoll (1977) state that these two families can be distinguished by the longer length of their vessel elements (seen in some of the fossils described here), distinctly heterogeneous rays and in that the constituent ray cells of the Icacinaceae are greater in height. However, these observations were based on mature wood and thus the distinction becomes less clear when dealing with immature 'twig'/stem and root wood especially when it is $\approx 50$

Figures 10-21. Anatomy of fossil Plataninium decipiens twigs and extant Platanus stems. Fig. 10. SEM RLS V.64757 showing gash-like and opposite vessel-ray pitting and scalariform perforation plate. Scale bar $=25 \mu \mathrm{m}$. Fig. 11 . SEM V.64757 in LS showing intervascular pitting and uniseriate, bordered fibre pits to the right of scalariform perforation plate. Scale bar $=50 \mu \mathrm{m}$. Fig. 12. TLS polished face V.64760 showing multiseriate ray. Scale bar $=150 \mu \mathrm{m}$. Fig. 13 . TLS polished face V.64760 showing vessels with tyloses and scalariform perforation plates with relatively few bars (arrowed). Scale bar $=150 \mu \mathrm{m}$. Fig. 14. RLS polished face of V.64760 showing ray cells. Scale bar $=150 \mu \mathrm{m}$. Fig. 15 . RLS Platanus $\times$ hispanica (Kew HK) showing ray vessel pits. Scale bar $=15 \mu \mathrm{m}$. Fig. 16. TS Platanus occidentalis L. (Kew). Scale bar $=500 \mu \mathrm{m}$. Fig. 17. TLS V.64757 showing the fibre pitting. Scale bar $=10 \mu \mathrm{m}$. Fig. 18. TLS Platanus kerrii (Kew Wheeler E no. 8745) showing multiseriate rays. Scale bar $=500 \mu \mathrm{m}$. Fig. 19. RLS Platanus $\times$ hispanica (Kew HK) showing procumbent- and relatively square ray cells with pits. Scale bar $=15 \mu \mathrm{m}$. Fig. 20. SEM the pith cells of Platanus $\times$ hispanica showing elongate and circular vessel ray pits scale bar $=10 \mu \mathrm{m}$. Fig. 21 . SEM of the pith cell pitting in V.64757. Scale bar $=25 \mu \mathrm{m}$. 

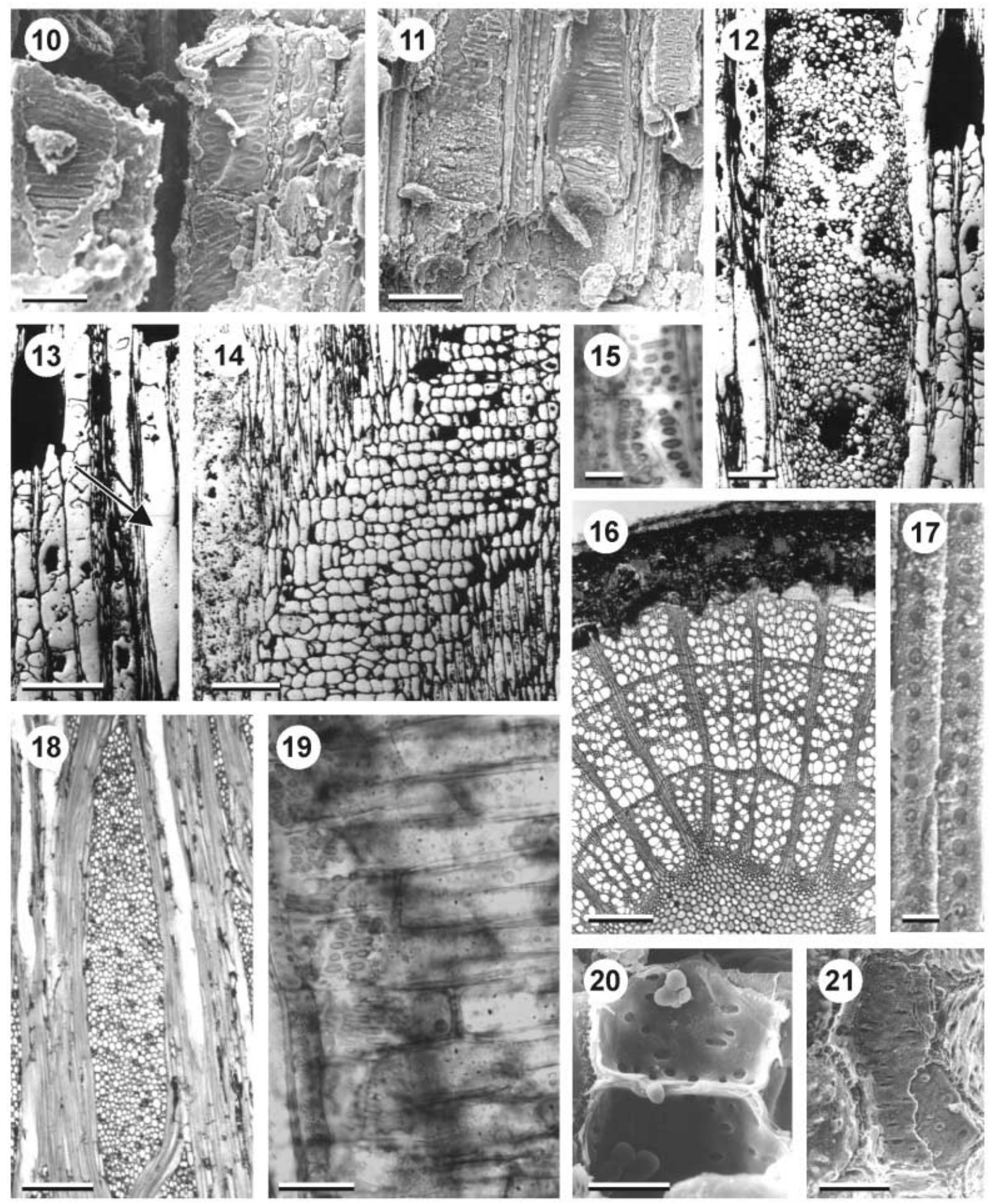


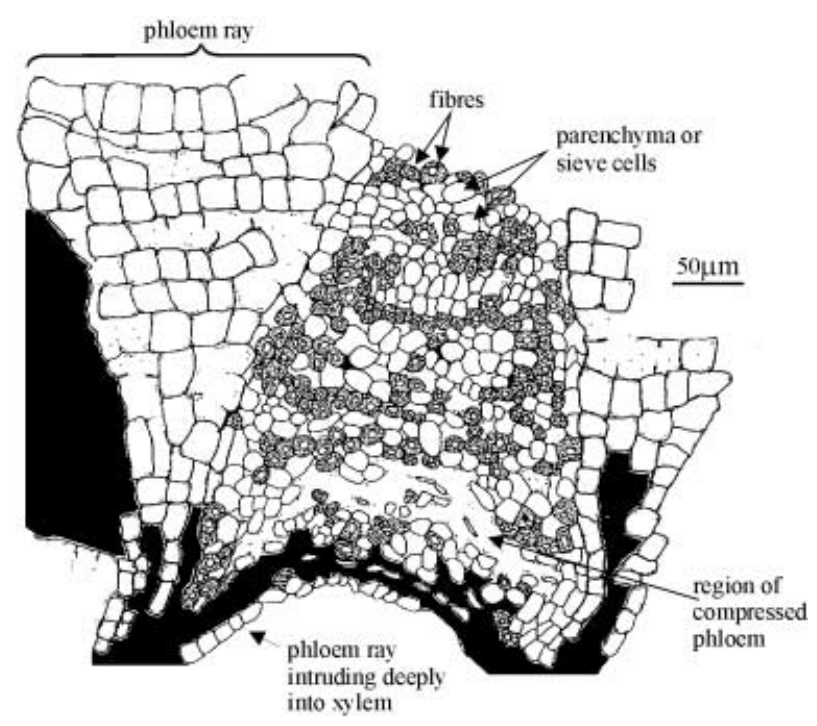

Figure 22. High magnification diagram illustrating the characteristic dilating rays and phloem wedges of $2 / 421$ (personal collection, species now disintegrated). Scale bar $=50 \mu \mathrm{m}$.

million years old. As already mentioned, rare, simple perforation plates were only observed in two of the seven specimens described. Such rare occurrences of simple perforation plates have been noted in Platanaceae although these are not usually observed in fossil platanaceous woods. Furthermore, elongated sheath-like cells, a feature of some Icacinaceae, have been noted in two specimens (V.64760 and V.64762). Moreover, it may be that the two specimens (V.64759 and V.64760) which lack a definite pith may be roots rather than stems (cf. Süss \& Müller-Stoll, 1977). Therefore, it is likely that there may be more than one group of platanoid wood present in the London Clay material. However, as the fossils are of immature 'twigs' and show only minor anatomical variation, we do not feel that we can subdivide these specimens further at this stage. When well-preserved mature specimens become available, this xylotype can be re-evaluated.

Baas (1969) described the anatomy of young twigs of Platanus kerrii Gagnep. This species exhibits the most primitive characters in the genus. Baas noted that $85 \%$ of the vessels have scalariform perforation plates and the vessel elements are longer than those in similar-aged stems of other Platanus species. Wheeler (1995) undertook a detailed study of mature wood of Platanus kerrii from Vietnam and found that the vessel elements are not significantly longer than those of other extant species of Platanus although the proportion of scalariform perforation plates was gen- erally greater. The rays of Platanus kerrii are the widest in the genus comprising up to 30 cells. However, our twigs differ anatomically from Platanus kerrii in that upright cells within the body of the rays are absent. Interestingly though, 'sheath cells' similar to those seen in V.64762 (Fig. 4) were observed in one specimen of Platanus kerrii (NHN Utrecht Branch, specimen U35081).

\section{COMPARISONS WITH FOSSIL TAXA}

Fossil woods from the Cretaceous and Tertiary similar to the London Clay platanoid woods are among the earliest known dicotyledonous woods, occurring as far back as the Albian (Thayn et al. 1985; Herendeen, 1991) and are usually assigned to either Plataninium, Platanoxylon or Icacinoxylon. Geologically ancient platanoid woods have exclusively scalariform perforation plates and very wide rays, i.e. up to 25 cells (Wheeler, 1995). The type genus Icacinoxylon is used for woods with large, markedly heterocellular, multiseriate rays alongside numerous uniseriate rays and predominantly solitary vessels (Wheeler et al., 1995). Plataninium is distinguished by the presence of large, multiseriate rays that are not markedly heterocellular and by the paucity or absence of uniseriate rays. However, as stated by Wheeler et al. (1995), there is a need to re-evaluate these organ genera as the boundaries between them and their species have become unclear.

Plataninium and Platanoxylon can be distinguished by the presence or absence of spiral thickenings - a feature not present in modern Platanus woods - such that fossil Platanus-like woods with spiral thickenings are placed in Plataninium (Süss \& Müller-Stoll, 1977). In advocating this much narrower circumscription for Plataninium, Süss \& Müller-Stoll (1977) undertook a review of the platanaceous fossil woods thus described and transferred many Plataninium species to Platanoxylon. Brett's Plataninium decipiens specimens, however, were retained in this organ genus because Süss and Müller-Stoll considered these specimens to be anatomically more similar to the Icacinaceae, based on their relatively long vessel members. Brett's Platanus sp. specimens were later assigned to Platanoxylon emend. Süss \& Müller-Stoll (1977) by Süss (1980). Differences between species of Plataninium are often quantitative and this makes dealing with juvenile or twig wood problematical as it is known that quantitative features vary according to distance from pith and chronological age (Carlquist, 1988; Poole, 1994).

Wilkinson (1984) described the first platanaceous/ icacinaceous fossil twig wood from the Isle of Sheppey (London Clay, Eocene) and illustrated its anatomy 
using scanning electron micrographs. She assigned her material to Plataninium sp. Plataninium had already been described from this and other localities around the south-east coast of England by Brett (1972) but Brett's material was calcified and originated from larger diameter trunk/branch material. The difference between the specimens described by Brett (1972), Wilkinson (1984) and those described herein are given in Table 1. From Table 1 it can be seen that these specimens differ in terms of quantitative features only (i.e. vessel diameter and abundance, ray width, ray abundance, vessel element length). However, qualitative features include rare, simple perforation plates in two of the specimens described here, and the obvious presence of crystals in the mature specimens of Plataninium decipiens (Brett, 1972). Because the twig material has some characters not fitting modern Platanaceae, is of the same geological age as those described by Brett (1972) and Wilkinson (1984) and because the anatomical distinctions are slight considering the relative maturity and diameter of the material, we believe that Wilkinson's material and the material described herein can be assigned to the same organ taxa as those described by Brett (1972).

\section{DISCUSSION}

The fossil record of Platanaceae extends back some $100 \mathrm{Myr}$ since leaves and reproductive features are known from the Albian (Crane et al., 1993). It seems likely that this family was more diverse during the Cretaceous and Tertiary than it is today (Manchester, 1986). Indeed, Wheeler \& Lehman (2000) suggest that the narrow diameter axes that they describe from Big Bend National Park (USA) might represent Platanaceae with a vine-like habit. The fossil record of platanoid wood is extensive, occurring at almost all localities where Cretaceous and early Tertiary dicotyledonous woods have been found including North America (e.g. Page, 1968; Süss \& Müller-Stoll, 1977; Scott \& Wheeler, 1982; Wheeler \& Lehman, 2000; Wheeler \& Manchester, 2002), Europe (e.g. Andreánsky, 1951; Greguss, 1969; Prakash et al. 1971; Brett, 1972; Süss \& Müller-Stoll, 1977; Wilkinson, 1984; Selmeier, 1996) and East Asia (Suzuki, 1976).

Today, the Platanaceae is a north temperate and subtropical family of trees comprising a single genus Platanus L. with two subgenera Platanus Leroy and Castaneophyllum Leroy. Members of the subgenus Platanus are native to temperate and subtropical areas (of North America and Europe) whereas Platanus kerrii, the only member of the subgenus Castaneophyllum, can be found in Indochina (Leroy,
1982). Platanus kerrii is morphologically distinct from subgenus Platanus in that it possesses elliptical to lanceolate leaves and long reproductive axes with 12 or more sessile heads (Leroy, 1982) rather than the familiar palmate leaves and reproductive axes that can range from solitary to several heads per peduncle. The current distribution of this species in Indochina is similar to other components of the paratropical rainforest of south-east England. Reid \& Chandler (1933) documented a $>60$ and 53\% similarity between fossils identified from the London Clay and living taxa found in India and South China-Burma, respectively. In addition to platanaceous pollen reported for the London Clay (Sein, 1961), leaves with superficial similarity to Platanus have been described from the underlying Woolwich and Reading Beds (Chandler, 1961). These records help to confirm the presence of platanaceous plants in the Lower Tertiary of south-east England.

\section{CONCLUSION}

This paper documents the occurrence of platanaceous twig wood, from the Eocene London Clay outcropping in both the London and Hampshire Basins of south-east England. These twigs, that form an abundant component of the twig flora, have been assigned to the organ genus Plataninium in accordance with the conclusions of Süss \& Müller-Stoll, (1977). The specimens described herein have been assigned to the species Plataninium decipiens erected by Brett (1972) and document for the first time the occurrence of this species in the London Clay twig flora. In undertaking this review, platanaceous twigs described by Wilkinson (1984) as an undefined species of Plataninium have also been assigned to the same species.

\section{ACKNOWLEDGEMENTS}

We thank Lindsey Axe and Laurence Badham of the Department of Earth Sciences, Cardiff University and members of the Electron Microscopy Unit at Royal Holloway University of London for the use of their facilities. We also thank Drs D. Cutler and P. Rudall (Anatomy Section of the Jodrell Laboratory, RBG, Kew) for allowing access to the wood slide collection and acknowledge Dr A.M.W. Mennega for useful comments and discussions. Dr S. Grimes supplied some of the material used in this study. We also acknowledge two anonymous reviewers whose comments helped to impove this manuscript. This research was undertaken in part whilst I.P. was in receipt of a Natural Environmental Research Council CASE award held jointly between the Royal Botanic 
Table 1. Summary of the anatomical features of the platanaceous material described from the Eocene of south-east England. V, vessel; $\varnothing$, diameter; t, tangential; r, radial, *, fibre-tracheids; - data not provided in original. Data from: ${ }^{1}$ Wilkinson (1984); ${ }^{2}$ Brett (1972); ${ }^{3}$ Baas (1969) and Wheeler (1995); ${ }^{4}$ data from personal observations in addition to that cited in Metcalfe \& Chalk (1950), Baas (1969) and Wheeler (1995). In the column headed 'extant Platanus' anatomical characters for immature small diameter stem (twig) wood of the two subgenera have been italicised when they differ from that of mature wood.

\begin{tabular}{|c|c|c|c|}
\hline Feature & $\begin{array}{l}\text { Plataninium twigs } \\
\text { herein }\end{array}$ & Plataninium sp. ${ }^{1}$ & Plataninium decipiens $^{2}$ \\
\hline Preservation & Pyritized & Pyritized & Silicified \\
\hline Organ type & Twig (stem, root) & Twig (stem) & Branch/trunk \\
\hline Growth rings & Absent & Absent & Indistinct \\
\hline \multicolumn{4}{|c|}{ Vessels range and (mean) } \\
\hline No. mm-2 & $19-54(65)$ & $30-46$ & $30-42$ \\
\hline Range V $\varnothing \mathrm{t}(\mu \mathrm{m})$ & $30-290(81)$ & $93-156(122)$ & $35-120(84)$ \\
\hline Range VØr $(\mu \mathrm{m})$ & $20-340(107)$ & $63-146(111)$ & - \\
\hline Element length $(\mu \mathrm{m})$ & $150-2500(792)$ & - & - \\
\hline Distribution & $\begin{array}{l}\text { Solitary, occasionally } \\
\text { paired due to } \\
\text { overlapping end walls }\end{array}$ & $\begin{array}{l}\text { Solitary, crowded, oblique, } \\
\text { some tangential rows of } \\
\quad \approx 3 \text { vessels }\end{array}$ & $\begin{array}{l}\text { Mostly solitary except } \\
\text { for overlapping end walls, } \\
\text { occasionally in tangential } \\
\text { rows of } 2-4 \text { vessels }\end{array}$ \\
\hline Porosity & Diffuse & Diffuse & Diffuse/weakly diffuse \\
\hline $\begin{array}{l}\text { Perforation plates } \\
\text { (No. bars) }\end{array}$ & $\begin{array}{l}\text { Scalariform with up to } \\
22 \text { bars or scalariform } \\
\text { and rare simple in } \\
\text { two specimens }\end{array}$ & $\begin{array}{l}\text { Scalariform with up to } 18 \\
\text { + bars }\end{array}$ & Scalariform with $13-32$ bars \\
\hline intervessel pitting & $\begin{array}{l}\text { Opposite, circular to } \\
\text { scalariform }\end{array}$ & Opposite & Opposite, scalariform \\
\hline \multicolumn{4}{|l|}{ Rays } \\
\hline Width (average) & $\begin{array}{l}\text { Rarely uniseriate, mainly } \\
\text { multiseriate } 5-20 \text { cells } \\
\text { wide }\end{array}$ & $\begin{array}{l}\text { Secondary rays } 2-5 \text { cells; } \\
\text { primary rays } 9-11 \text { cells }\end{array}$ & $2-24$ cells \\
\hline Height $(\mu \mathrm{m})$ & Up to 8000 & $\approx 8500$ & $\begin{array}{l}\text { 1000-6000, acutely } \\
\text { tapered at margins }\end{array}$ \\
\hline Ray vessel pitting & $\begin{array}{l}\text { Circular, opposite to } \\
\text { scalariform }\end{array}$ & Opposite and gash-like & - \\
\hline Crystals & None observed & - & Present \\
\hline Cellular composition & $\begin{array}{l}\text { Procumbent, square, } \\
\text { occasionally upright } \\
\text { body cells; square } \\
\text { marginal cells }\end{array}$ & $\begin{array}{l}\text { Wide rays procumbent } \\
\text { body cells; narrow rays } \\
\text { with relatively square } \\
\text { to upright body cells }\end{array}$ & $\begin{array}{l}\text { Procumbent body cells with } \\
\text { relatively squarer cells } \\
\text { forming marginal rows }\end{array}$ \\
\hline No. per mm & $1-6$ & $1-5$ & $1-3$ \\
\hline \multicolumn{4}{|l|}{ Parenchyma } \\
\hline Distribution & $\begin{array}{l}\text { Difficult to distinguish } \\
\text { from fibres; ?scanty }\end{array}$ & $\begin{array}{l}\text { Vasicentric paratracheal: } \\
\text { narrow sheath }\end{array}$ & $\begin{array}{l}\text { Diffuse in short wavy } \\
\text { bands of cells, abundant }\end{array}$ \\
\hline \multicolumn{4}{|l|}{ Fibres } \\
\hline Range $\varnothing \mu \mathrm{m}$ & $8-30$ & - & - \\
\hline Pits & Bordered & Bordered & - \\
\hline Phloem & Separated by dilating rays & Absent & Absent \\
\hline
\end{tabular}


Extant Platanus subgenus

\begin{tabular}{|c|c|c|}
\hline \multirow[b]{2}{*}{ Platanus $\mathrm{sp}^{2}$} & \\
\hline & Platanus ${ }^{3,4}$ & Castaneophyllum ${ }^{3,4}$ \\
\hline \multicolumn{3}{|l|}{ Calcified } \\
\hline Branch/trunk & Mature and twig wood & Mature and twig wood \\
\hline $\begin{array}{l}\text { Distinct marked by several rows } \\
\text { of flattened fibres }\end{array}$ & Distinct & $\begin{array}{l}\text { Indistinct marked by radially } \\
\text { shortened cells and crystals in } \\
\text { rays; present }\end{array}$ \\
\hline 150 & $\approx 70$ & $30-56$ \\
\hline $20-72(50)$ & $50-100(<100)$ & $51-127(94)$ \\
\hline- & $\begin{array}{l}34-128(69) \\
18-75(43)\end{array}$ & $\begin{array}{l}60-165(117) \\
30-75(49)\end{array}$ \\
\hline- & $\begin{array}{l}600-875(500-800) \\
160-850(466)\end{array}$ & $\begin{array}{l}443-880(648) \\
240-710(560)\end{array}$ \\
\hline $\begin{array}{l}\text { Crowded in multiples, irregular } \\
\text { clusters; late wood more } \\
\text { solitary and less numerous }\end{array}$ & $\begin{array}{l}\text { Solitary and in radial pairs and } \\
\text { threes; oblique and tangential } \\
\text { pairs and groups }\end{array}$ & $\begin{array}{l}\text { Mostly solitary (relatively angular } \\
\text { in outline), also in oblique and } \\
\text { tangential pairs }\end{array}$ \\
\hline Diffuse & Diffuse & Diffuse \\
\hline Scalariform with $8-16$ bars & $\begin{array}{l}\text { Simple and scalariform with up } \\
\text { to c. } 20 \text { bars }\end{array}$ & $\begin{array}{l}\text { Simple and scalariform 1-24 (53\%, } \\
82 \%) \text { with } 2-22(-30), 1-24(7) \\
\text { bars }\end{array}$ \\
\hline Opposite & $\begin{array}{l}\text { Opposite (horizontally elongate } \\
\text { alternate) }\end{array}$ & Opposite (scalariform) \\
\hline $\begin{array}{l}\text { Uniseriate, rare part- } \\
\text { Uniseriate, mostly broad up to } 22 \\
\text { cells wide ( } 7 \text { ) }\end{array}$ & $\begin{array}{l}\text { Few uniseriate rays if present; } \\
\text { multiseriate } 12-15(-20) \\
\text { cells }\end{array}$ & Rarely uniseriate \\
\hline $\begin{array}{l}2000-3000 \text { (-6000 and dissected } \\
\text { diagonally by fibres) }\end{array}$ & 2000-3000, often dissected & 449-2873, dissected \\
\hline- & $\begin{array}{l}\text { Circular, opposite, elongate; } \\
\text { circular- elongate, gash like }\end{array}$ & Circular to elongate \\
\hline Present & Present & Present \\
\hline $\begin{array}{l}\text { Procumbent body cells with } \\
\text { relatively squarer cells } \\
\text { forming marginal rows }\end{array}$ & $\begin{array}{l}\text { Homocellular with procumbent } \\
\text { body cells, sometimes more } \\
\text { square }\end{array}$ & $\begin{array}{l}\text { Upright/square in uniseriate rays; } \\
\text { with procumbent (with upright } \\
\text { cells) with square/upright } \\
\text { marginals in multiseriate rays }\end{array}$ \\
\hline 3 & $0-2,1-3$ & $0-2,2-3$ \\
\hline $\begin{array}{l}\text { Diffuse in short wavy bands of } \\
\text { cells }\end{array}$ & $\begin{array}{l}\text { Apotracheal, diffuse, sometimes } \\
\text { in uniseriate bands }\end{array}$ & $\begin{array}{l}\text { Apotracheal diffuse to diffuse in } \\
\text { aggregate, very scanty, plus } \\
\text { scanty paratracheal }\end{array}$ \\
\hline $15-20$ & $18-21(20)$ & 9-32 (20), 4-12 (9) \\
\hline Bordered & Bordered & $*$ Bordered \\
\hline Absent & Separated by dilating rays & Separated by dilating rays \\
\hline
\end{tabular}


Gardens, Kew and Royal Holloway, University of London and in part by NERC grant number GR3/11196 to Professors D.E.G. Briggs, D. Edwards, D. Rickard and J. Parkes. Both grants are gratefully acknowledged.

\section{REFERENCES}

Andreánsky G. 1951. Der versteinerte Wald von Mikófalva und einige andere verkieselte Baumstämme aus Ungarn. Annales Biologicae Universiatum Hungariae 1: 15-24.

Baas P. 1969. Comparative anatomy of Platanus kerrii Gagnep. Botanical Journal of the Linnean Society 62: 413-421.

Brett DW. 1972. Fossil wood of Platanus from the British Eocene. Palaeontology 15: 496-500.

Brummitt RK, Powell CE. 1992. Authors of plant names. Kew: Royal Botanic Gardens.

Carlquist S. 1988. Comparative wood anatomy. Systematic, ecological and evolutionary aspects of dicotyledon wood. Berlin: Springer-Verlag.

Chandler MEJ. 1961. The lower Tertiary floras of southern England I. Palaeocene floras, London Clay flora. London: British Museum (Natural History).

Cornish L. 1987. The treatment of decaying pyritiferous fossil material using ethanolamine thioglycolate. Geological Curator 4: 451-454.

Crane PR, Pederson KR, Friis EM, Drinnan AN. 1993. Early Cretaceous (Early to Middle Albian) platanoid inflorescences associated with Sapindopsis leaves from the Potomac Group of eastern North America. Systematic Botany 18: $328-344$.

Greguss P. 1969. Tertiary angiosperm woods in Hungary. Budapest: Akadémiai Kiadó.

Herendeen PS. 1991. Charcoalified angiosperm wood from the Cretaceous of eastern North America and Europe. Review of Palaeobotany and Palynology 69: 225-239.

IAWA Committee. 1989. IAWA list of microscopic features for hardwood identification. International Association of Wood Anatomists Bulletin 10: 219-332.

Ilic J. 1987. The CSIRO family key for hardwood identification. Leiden: EJ Brill.

Ilic J. 1991. CSIRO Atlas of hardwoods. Australia: Crawford House Press \& CSIRO Publications.

Kenrick P, Edwards D. 1988. The anatomy of Lower Devonian Gosslingia breconensis Heard based on pyritized axes, with some comments on the permineralization process. Botanical Journal of the Linnean Society 97: 95-123.

King C. 1984. The stratigraphy of the London Clay Formation and Virginia Water Formation in the coastal sections of the Isle of Sheppey (Kent, England). Tertiary Research 5: 121-160.

LaPasha CA, Wheeler EA. 1987. A microcomputer based system for computer-aided wood identification. International Association of Wood Anatomists Bulletin 8: 347-354.

Leroy J-F. 1982. Botanique-origine et évolution du genre Platanus (Platanaceae). Comptes Rendus de l'Académie des Sciences - Series III. Sciences de la Vie 295: 251-254.
Manchester SR. 1986. Vegetative and reproductive morphology of extinct plane trees (Platanaceae) from the Eocene of western North America. Botanical Gazette 147: 200-226.

Metcalfe CR, Chalk L. 1950. Anatomy of the dicotyledons. Vols 1 and 2. Oxford: Clarendon Press.

Metcalfe CR, Chalk L. 1983. Anatomy of the dicotyledons II. Wood structure and conclusions of the general introduction. Oxford: Clarendon Press.

Miles A. 1978. Photomicrographs of world woods. London: HMSO Building Research Establishments.

Page VM. 1968. Angiosperm wood from the upper Cretaceous of central California. American Journal of Botany 55: $168-172$.

Poole I. 1993. A dipterocarpaceous twig from the Eocene London Clay Formation of Southeast England. Special Papers in Palaeontology 49: 155-163.

Poole I. 1994. Twig wood anatomical characters as palaeoecological indicators. Review of Palaeobotany and Palynology 81: $33-52$.

Prakash U, Březinová D, Bùžek È. 1971. Fossil woods from the Doupovskéhory and Èeské støedohoøí Mountains in Northern Bohemia. Palaeontographica Abteilung B 133: 103-128.

Reid EM, Chandler MEJ. 1933. The flora of the London Clay. London: British Museum (Natural History).

Schweingruber FH. 1990. Anatomie Europäischer Hölzer. Anatomy of European Woods. Berne and Stuttgart: Paul Haupt.

Scott RA, Wheeler EA. 1982. Fossil woods from the Eocene Clarno Formation of Oregon. International Association of Wood Anatomists Bulletin 3: 135-154.

Sein MA. 1961. Fossil Spores of the London Clay. DPhil Thesis, University of London.

Selmeier A. 1996. Tertiary Platanus woods from the northalpine Molasse basin (Austria Germany). Mitteilungen Bayerische Staatsammlung Paleaontologische und Historische Geologie 36: 157-183.

Süss H. 1980. Ein Platanenholz aus dem Untereozan der Greifswalder Oie Platanoxylon cohenii (Schuster) comb. nov. Schriftenreihe Geologischen Wissenschaften Berlin 16: 401-416.

Süss H, Müller-Stoll WR. 1977. Zur Anatomie des AstStamm- und Wurzelhölzes von Platanus x acerifolia (Ait.) Willd. Österreichische Botanische Zeitung 121: 227-249.

Suzuki M. 1976. Some fossil woods from the Palaeogene of northern Kyushu. Botanical Magazine of Tokyo 89: 59-71.

Thayn GF, Tidwell WD, Stokes WL. 1985. Flora of the Lower Cretaceous Cedar Mountain Formation of Utah and Colorado. Part III. Icacinoxylon pittiense n. sp. American Journal of Botany 72: 175-180.

Wheeler EA. 1995. Wood of Platanus kerrii. International Association of Wood Anatomists Journal 16: 127-132.

Wheeler EA, Pearson RG, LaPasha CA, Zack T, Hatley W. 1986. Computer-aided wood identification. Raleigh: North Carolina Agricultural Research Service Bulletin 474 . 
Wheeler EA, Lehman TM. 2000. Late Cretaceous woody dicots from the Aguja and Javelina Formations, Big Bend National Park, Texas, USA. International Association of Wood Anatomists Journal 21: 83-120.

Wheeler EA, Manchester SR. 2002. Woods of the middle Eocene Nut Beds flora, Clarno Formation, Oregon, USA. International Association of Wood Anatomists Journal 3S: $1-188$.
Wheeler EA, McClammer J, LaPasha CA. 1995. Similarities and differences in dicotyledonous woods of the Cretaceous and Paleocene. San Juan Basin, New Mexico, USA. International Association of Wood Anatomists Journal 16: $223-254$.

Wilkinson HP. 1984. Pyritised twigs from Sheppey. Tertiary Research 5: 189-198. 